\title{
molecules
}

ISSN 1420-3049

www.mdpi.com/journal/molecules

Article

\section{Chemical Composition, Biological and Cytotoxic Activities of Plant Extracts and Compounds Isolated from Ferula lutea}

\author{
Mansour Znati ${ }^{1,2}$, Hichem Ben Jannet ${ }^{2, *}$, Sylvie Cazaux ${ }^{1}$ and Jalloul Bouajila ${ }^{1, *}$ \\ 1 Laboratoire des IMRCP UMR CNRS 5623, Faculté de pharmacie de Toulouse, Université de \\ Toulouse, Université Paul-Sabatier, 118 route de Narbonne, Toulouse F-31062, France \\ 2 Laboratoire de Chimie Hétérocyclique, Produits Naturels et Réactivité (CHPNR), Equipe Chimie \\ Médicinale et Produits Naturels, Département de Chimie, Faculté des Sciences de Monastir, \\ Université de Monastir, Avenue de l’Environnement, Monastir 5019, Tunisia \\ * Authors to whom correspondence should be addressed; E-Mails: hichem.benjannet@yahoo.fr (H.B.J.); \\ jalloul.bouajila@univ-tlse3.fr (J.B.); Tel: +21-673-500-279 (H.B.J.); \\ Fax: +21-673-500-278 (H.B.J.); Tel./Fax: +33-562-256-885 (J.B.).
}

Received: 24 December 2013; in revised form: 14 February 2014 / Accepted: 18 February 2014 / Published: 26 February 2014

\begin{abstract}
The present work describes the phytochemical study on Ferula lutea flowers. Total phenolics and flavonoids of the $n$-butanol and ethyl acetate extracts were quantified (phenolics [40.68-52.29 mg gallic acid equivalent/g of dry weight], flavonoids [12.38-14.72 mg quercitin/g dry weight]). Two diastereoisomers were isolated and identified using spectroscopic techniques (1D, 2D NMR and GC-MS). The extracts and diastereoisomers were tested for antioxidant, antiacetylcholinesterase, antimicrobial, antidiabectic, cytotoxic (leukemia cell line) activities and allelopathic potentialities. The strongest antioxidant activity was obtained for the ethyl acetate extract $\left(\mathrm{IC}_{50}=12.8 \pm 1.29 \mu \mathrm{g} / \mathrm{mL}\right)$. The two extracts exhibited high antidiabetic activity $(54.1$ and $52.1 \%$ at $40 \mu \mathrm{g} / \mathrm{mL})$.
\end{abstract}

Keywords: Ferula lutea; (+)-Z-deltoin; (-)-E-deltoin; antioxidant; antiacetylcholinesterase; antimicrobial; antidiabetic; cytotoxic; allelopathic

\section{Introduction}

Plants still serve as a far reaching source of innovative and original compositions on the structural level. These new compounds serve as a clue for the discovery of new medicines, herbal and practical 
foods. There is an escalating interest in naturally occurring antioxidants to replace synthetic counterparts used for food conservation, flavoring, and cosmetics, as well as in health care.

The genus Ferula (family Apiaceae) comprises 170 species [1], mostly growing in arid regions of temperate Eurasia, in the Canary Islands and in North Africa. The center of diversity of the genus is situated in W. and C. Asia [2]. In Tunisia, only four species of the Ferula genus have been identified: $F$. communis, F. lutea, F. tunetana and F. tingitana [3]. Several species of this genus have been used in folk medicine in several countries. The gum resins of the roots from several Ferula species are reported to be used for stomach disorders, rheumatism, headache, arthritis, and dizziness [4,5]. Some species are used in traditional foods as well as in traditional medicine as treatments for skin infections [6] and diabetes, and prevent convulsion and hysteria [7]. It is known that the genus Ferula contains a variety of coumarins [8] and sesquiterpenes [9]. Chemical investigations on F. communis also led to the isolation of coumarins [10,11] and sesquiterpenes [11]. Various biological activities have been reported for the essential oils of some species of Ferula, such as antioxidant [12], cytotoxicity [13] and antibacterial properties [14]. Natural products bearing coumarin moieties have shown a variety of biological activities $[15,16]$. Coumarins such as $(-)$-deltoin are hepatoprotective and show TNF- $\alpha$ inhibitory activity [16]. The roots of $F$. lutea were the subject of a previous phytochemical investigation, undertaken in our laboratory, leading to the isolation of new dihydrofuranocoumarins as two inseparable isomers, (-)-5-hydroxyprantschimgin and (-)-5-hydroxydeltoin, together with eight known compounds, (-)-prantschimgin, (-)-deltoin, psoralen, xanthotoxin, umbelliferone, caffeic acid, $\beta$-sitosterol and stigmasterol [17]. The essential oil obtained from $F$. lutea flowers has recently been shown to contain various terpenoidal compounds [18].

In this work, we report the, antioxidant, antiacetylcholinesterase, antimicrobial, antidiabetic, allelopathic and cytotoxic activities of the ethyl acetate and the $n$-butanol extract of $F$. lutea flowers and the isolation, and identification of two diastereoisomers in the mixture. This is the first time that extracts and compounds $\mathbf{1 a}$ and $\mathbf{1 b}$ were evaluated for biological activities.

\section{Results and Discussion}

\subsection{Extraction Yields}

Extraction yields of $F$. lutea flowers are presented in Table 1. The $n$-butanol extract had the highest yield $(3.79 \%$ ), while the ethyl acetate one gave $0.96 \%$. No data on extraction yields of this plant have been found in the literature.

Table 1. Yields and chemical composition of F. lutea flowers extracts.

\begin{tabular}{cccc}
\hline Extracts & Yield (\%) & Phenolics (GAE) $^{\mathbf{a}}$ & Flavonoids (QE) $^{\mathbf{a}}$ \\
\hline Ethyl acetate & 0.96 & $40.7 \pm 0.2$ & $12.4 \pm 0.1$ \\
$n$-Butanol & 3.79 & $52.3 \pm 0.4$ & $14.7 \pm 0.1$ \\
\hline
\end{tabular}

GAE: gallic acid equivalents. QE: quercetin equivalent. ${ }^{a}: \mathrm{mg} / \mathrm{g}$ dry weight.

\subsection{Isolation and Structure Elucidation of Compounds $\mathbf{1 a}+\mathbf{1 b}$}

The mixture of compounds 1a and 1b was isolated as a yellow oil and it showed on TLC a spot featuring a characteristic blue fluorescence under UV light. EI GC-MS analysis of the mixture gave for 
both a molecular ion peak $[\mathrm{M}]^{+}$at $m / z 328$ indicating a common molecular formula of $\mathrm{C}_{19} \mathrm{H}_{20} \mathrm{O}_{4}$. The structure of 1a and $\mathbf{1 b}$ (Figure 1) were elucidated on the basis of the ${ }^{1} \mathrm{H}$ - and ${ }^{13} \mathrm{C}-\mathrm{NMR}$ spectral data (Table 2).

Figure 1. Structure of $(+)$-Z-deltoin (1a, major compound) and (-)-E-deltoin (1b, minor compound).

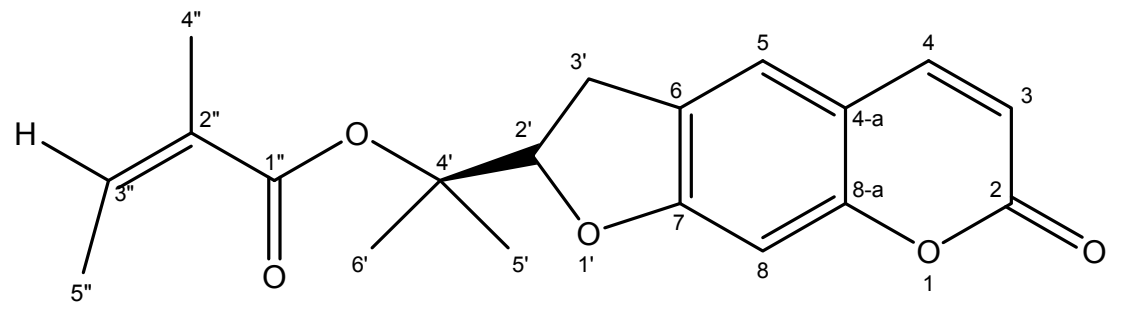

(1a)<smiles>CC(C(=O)OC(C)(F)C1Cc2cc3ccc(=O)oc3cc2O1)=C(F)F</smiles>

(1b)

Table 2. ${ }^{1} \mathrm{H}$ - and ${ }^{13} \mathrm{C}-\mathrm{NMR}$ spectroscopic data of the two diastereoisomers (1a and $\left.\mathbf{1 b}\right)$.

\begin{tabular}{|c|c|c|c|c|c|c|}
\hline \multirow{2}{*}{ Position } & \multicolumn{3}{|c|}{$1 \mathbf{a}$} & \multicolumn{3}{|c|}{$1 \mathrm{~b}$} \\
\hline & $\delta_{\mathrm{H}}$ & Multiplicity $J(H z)$ & $\boldsymbol{\delta}_{\mathbf{C}}$ & $\delta_{H}$ & Multiplicity $J(\mathbf{H z})$ & $\boldsymbol{\delta}_{\mathbf{C}}$ \\
\hline 2 & - & - & 160.99 & - & - & 161.51 \\
\hline 3 & 6.17 & $\mathrm{~d}(9.6)$ & 111.64 & 6.20 & $d(9.6)$ & 112.26 \\
\hline 4 & 7.57 & $\mathrm{~d}(9.6)$ & 143.28 & 7.56 & $\mathrm{~d}(9.6)$ & 143.78 \\
\hline 5 & 7.19 & $\mathrm{~s}$ & 122.76 & 7.14 & $\mathrm{~s}$ & 123.20 \\
\hline 6 & - & - & 124.04 & - & - & 124.50 \\
\hline 7 & - & - & 162,89 & - & - & 163.44 \\
\hline 8 & 6.69 & $\mathrm{~s}$ & 97.26 & 6.76 & $\mathrm{~s}$ & 97.84 \\
\hline 4-a & - & - & 112.11 & - & - & 112.21 \\
\hline $8-\mathrm{a}$ & - & - & 155.18 & - & - & 155.75 \\
\hline $2^{\prime}$ & 5.02 & $\mathrm{t}(9)$ & 88.67 & 5.12 & $\mathrm{~m}$ & 88.91 \\
\hline $3 '-a$ & $3.10-3.30$ & $\mathrm{~m}$ & & $3.10-3.30$ & $\mathrm{~m}$ & \\
\hline 3'-b & $3.10-3.30$ & $\mathrm{~m}$ & 29.06 & $3.10-3.30$ & $\mathrm{~m}$ & 29.61 \\
\hline $4^{\prime}$ & - & - & 81.49 & - & - & 82.04 \\
\hline \multirow[t]{2}{*}{$5^{\prime}$} & 1.58 & $\mathrm{~s}$ & 20.94 & 1.37 & $\mathrm{~s}$ & 20.58 \\
\hline & 1.59 & $\mathrm{~s}$ & 21.73 & 1.39 & $\mathrm{~s}$ & 21.47 \\
\hline $1 "$ & - & - & 166.57 & - & - & 168.67 \\
\hline $2^{\prime \prime}$ & - & - & 128.11 & - & - & 127.33 \\
\hline $3 "$ & 5.95 & $\mathrm{qq}(7.2 ; 1.5)$ & 137.28 & 6.09 & $\mathrm{qq}(7.2 ; 1.2)$ & 137.74 \\
\hline $4 "$ & 1.63 & $\mathrm{~m}$ & 19.56 & 1.63 & $\mathrm{~m}$ & 20.09 \\
\hline $5^{\prime \prime}$ & 1.87 & $\mathrm{~m}$ & 15.13 & 1.85 & $\mathrm{~m}$ & 15.64 \\
\hline
\end{tabular}

The ${ }^{1} \mathrm{H}-\mathrm{NMR}$ spectrum showed the duplication of all the proton signals of deltoin (Figure 2) [19]. This spectrum showed two signals at $\delta_{\mathrm{H}} 6.17(1 \mathrm{H}, \mathrm{d}, J=9.6 \mathrm{~Hz})$ and $\delta_{\mathrm{H}} 7.57(1 \mathrm{H}, \mathrm{d}, J=9.6 \mathrm{~Hz})$ as 
AB-type signals, attributable to $\mathrm{H}-3$ and $\mathrm{H}-4$ in 1a, respectively. A second AB-type spin system was also observed at $\delta_{\mathrm{H}} 6.20(1 \mathrm{H}, \mathrm{d}, J=9.6 \mathrm{~Hz})$ and $\delta_{\mathrm{H}} 7.56(1 \mathrm{H}, \mathrm{d}, J=9.6 \mathrm{~Hz})$, corresponding to $\mathrm{H}-3$ and $\mathrm{H}-4$ in $\mathbf{1 b}$, respectively.

Figure 2. Duplication of signals in ${ }^{1} \mathrm{H}-\mathrm{NMR}$ of the mixture of compounds $\mathbf{1 a}$ and $\mathbf{1 b}$.

\section{Duplication of signals}

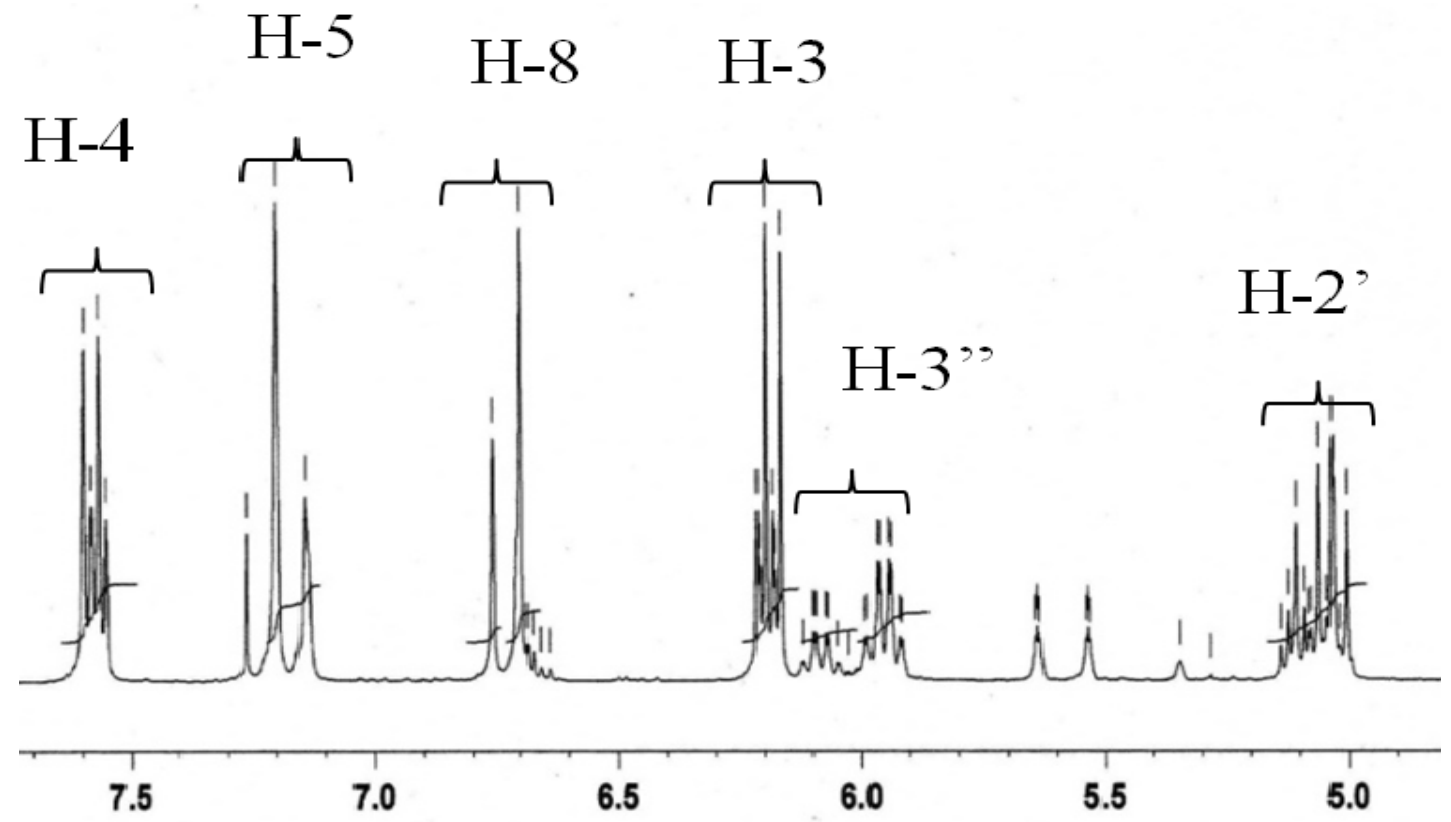

The same spectrum showed two pair of singlets at $\delta_{\mathrm{H}} 6.69(1 \mathrm{H}, \mathrm{s}, \mathbf{1 a})$ and $\delta_{\mathrm{H}} 7.19(1 \mathrm{H}, \mathrm{s}, \mathbf{1 a})$ and at $\delta_{\mathrm{H}} 6.76(1 \mathrm{H}, \mathrm{s}, \mathbf{1 b})$ and $\delta_{\mathrm{H}} 7.14(1 \mathrm{H}, \mathrm{s}, \mathbf{1 b})$ corresponding to the aromatic protons $\mathrm{H}-8$ and $\mathrm{H}-5$, respectively. The observation in the same spectrum of a triplet at $\delta_{\mathrm{H}} 5.02(1 \mathrm{H}, \mathrm{t}, J=9 \mathrm{~Hz}, \mathrm{H}-2$ ', 1a) and a multiplet at $\delta_{\mathrm{H}} 5.12\left(1 \mathrm{H}, \mathrm{m}, \mathrm{H}-2\right.$, 1a) a multiplet at $\delta_{\mathrm{H}} 3.10-3.30(4 \mathrm{H}, \mathrm{m}$, H-3'a,b, 1a and 1b) suggested the presence of the dihydrofuranic moiety in 1a and 1b [17,19-24]. These data and the observed duplication of all the signals are in good concordance with the dihydrofuranocoumarin structure of $\mathbf{1 a}$ and $\mathbf{1 b}$. The two methyl groups attached at C-4' in both $\mathbf{1 a}$ and 1b were identified according to the two pair of singlets at $\delta_{\mathrm{H}} 1.58\left(3 \mathrm{H}, \mathrm{s}, \mathrm{H}-5^{\prime}\right)$ and $1.59\left(3 \mathrm{H}, \mathrm{s}, \mathrm{H}-6^{\prime}\right)$ and at $\delta_{\mathrm{H}} 1.37\left(3 \mathrm{H}, \mathrm{s}, \mathrm{H}-5^{\prime}\right)$ and $1.39\left(3 \mathrm{H}, \mathrm{s}, \mathrm{H}-6^{\prime}\right)$, respectively. The other signals at $\delta_{\mathrm{H}} 5.95(1 \mathrm{H}, \mathrm{qq}$, $J=7.2 ; 1.5 \mathrm{~Hz}, \mathrm{H}-3 ", 1 \mathbf{1 a})$, at $\delta_{\mathrm{H}} 1.63(3 \mathrm{H}, \mathrm{m}, \mathrm{H}-4 ", \mathbf{1 a})$, at $\delta_{\mathrm{H}} 1.87(3 \mathrm{H}, \mathrm{m}, \mathrm{H}-5 ", \mathbf{1 a})$, at $\delta_{\mathrm{H}} 6.09(1 \mathrm{H}$, qq, $J=7.2 ; 1.2 \mathrm{~Hz}, \mathrm{H}-3 ", \mathbf{1 b})$, at $\delta_{\mathrm{H}} 1.63(3 \mathrm{H}, \mathrm{m}, \mathrm{H}-4 ", \mathbf{b})$, at $\delta_{\mathrm{H}} 1.85(3 \mathrm{H}, \mathrm{m}, \mathrm{H}-5 ", 1 \mathbf{b})$ coincide with the spectral data of an angeloyl moiety in $\mathbf{1 a}$ and $\mathbf{1 b}$ with two different configurations (Figure 1).

The ${ }^{13} \mathrm{C}$-NMR spectrum showed the duplication of most signals including those attributed to the common dihydrofuranocoumarin system and those of the angeloyl moiety confirming that the analyzed sample is a mixture of two diastereoisomeric forms $\mathbf{1 a}$ and $\mathbf{1 b}$ (Table 2).

The stereochemical proposal for carbon C-2' in 1a has been attributed based on comparison of the chemical shift of H-2' $\left(\delta_{\mathrm{H}} 5.09\right)$ to the literature data [20]. On the other hand, the $(Z)$ configuration of the double bond in the angeloyl fragment in 1a was evidenced from the NOESY spectrum showing the dipolar interaction of the ethylenic proton $\mathrm{H}-3$ " ( $\left.\delta_{\mathrm{H}} 5.95, \mathrm{qq}, J_{1}=7.2 \mathrm{~Hz}, J_{2}=1.5 \mathrm{~Hz}\right)$ with both methyl 
groups $\left(\mathrm{CH}_{3}\right)-4 "\left(\delta_{\mathrm{H}} 1.63, \mathrm{~m}\right)$ and $\left(\mathrm{CH}_{3}\right)-5 "\left(\delta_{\mathrm{H}} 1.87, \mathrm{~m}\right)$, whereas, the $(E)$ configuration of the same double bond in the angeloyl moiety in $\mathbf{1 b}$ was proved by the unique $n O e$ between $\mathrm{H}-3$ " $\left(\delta_{\mathrm{H}} 6.09\right.$, qq, $J=7.2 ; 1.2 \mathrm{~Hz})$, and $\mathrm{H}-5 "\left(\delta_{\mathrm{H}} 1.85, \mathrm{~m}\right)$ revealed from the same NOESY spectrum.

The various plants and organs containing compounds $\mathbf{1 a}$ and $\mathbf{1 b}$ are grouped in Table 3. Compound 1a was never previously isolated from any Ferula species, but it was previously isolated from Seseli peucedanoides (roots) and Heracleum candolleanum (seeds or roots), while compound $\mathbf{1 b}$ was isolated from Peucedanum japonicum (roots), Seseli resinosum (roots) and Ferula lutea (roots). Compounds 1a and $\mathbf{1 b}$ were identified for the first time in the $F$. lutea flowers.

Table 3. Various plants and organs containing compounds $\mathbf{1 a}$ and $\mathbf{1 b .}$

\begin{tabular}{ccc}
\hline Compound & Plant & Reference \\
\hline $\mathbf{1 a}$ & Seseli peucedanoides (roots) & {$[21]$} \\
& Heracleum candolleanum (seeds or roots) & {$[22]$} \\
$\mathbf{1 b}$ & Ferula lutea (root) & {$[17]$} \\
& Peucedanum japonicum (root) & {$[23]$} \\
& Seseli resinosum (root) & {$[24]$} \\
\hline
\end{tabular}

\subsection{Phenolics and Flavonoids Content}

The amount of total phenolics and flavonoids content in the extracts of $F$. lutea flowers are shown in Table 1. The $n$-butanol extract had the highest quantity $(52.3 \pm 0.4 \mathrm{mg} \mathrm{GAE} / \mathrm{g}$ of dry weight) followed by the ethyl acetate extract ( $40.7 \pm 0.2 \mathrm{mg}$ GAE/g of dry weight). The flavonoids content of the $n$-butanol extract was the highest (14.7 mg QE/g dry weight) while the ethyl acetate extract had $12.4 \pm 0.1 \mathrm{mg} \mathrm{QE} / \mathrm{g}$ dry weight. The phenolics and flavonoids content of $F$. lutea has not been reported in the literature. The study of other species and organs ( $F$. assafoetida, aerial parts) showed that the total phenolics were $94.8 \pm 5.9 \mathrm{mg} \mathrm{GAE} / \mathrm{g}$ of dry weight and total flavonoids were $90.9 \pm 6.9 \mathrm{mg} \mathrm{QE} / \mathrm{g}$ dry weight [25].

\subsection{Antioxidant Activity}

The antioxidant activity of the extracts assayed using two methods (DPPH and ABTS) is presented in Table 4. By the DPPH test, the best result was obtained with the ethyl acetate extract $\left(\mathrm{IC}_{50}=12.8 \pm 1.3 \mu \mathrm{g} / \mathrm{mL}\right)$ followed by the $n$-butanol extract $\left(\mathrm{IC}_{50}=26.0 \pm 1.8 \mu \mathrm{g} / \mathrm{mL}\right)$. The two extracts have good antioxidant activity compared to the positive control, L-ascorbic acid (Vit C, $\mathrm{IC}_{50}=4.4 \pm 0.1 \mu \mathrm{g} / \mathrm{mL}$ ). The ABTS assay confirmed the DPPH assay results, with the ethyl acetate showing an $\mathrm{IC}_{50}=184.0 \pm 7.0 \mu \mathrm{g} / \mathrm{mL}$ and therefore better antioxidant activity than the $n$-butanol extract $\left(\mathrm{IC}_{50}=300.0 \pm 5.0 \mu \mathrm{g} / \mathrm{mL}\right)$. The antioxidant activity (DPPH and ABTS) of F. lutea extracts has not been cited in the literature before. For this genus, only $F$. gummosa Boiss roots [26] was evaluated for antioxidant activity with the DPPH assay giving an $\mathrm{IC}_{50}=579.6 \pm 19.4 \mu \mathrm{g} / \mathrm{mL}$. 
Table 4. Antioxidant, antiacetylcholinesterase, antidiabetic and cytotoxic activities of $F$. lutea extracts and the mixture $(\mathbf{1} \mathbf{a}+\mathbf{1 b})$.

\begin{tabular}{|c|c|c|c|c|c|}
\hline Samples & DPPH Assay $^{a}$ & ABTS $^{+}$Assay $^{a}$ & $\begin{array}{c}\text { Antiacetylcholinesterase } \\
\text { Activity }^{\text {a }} \\
\end{array}$ & $\begin{array}{l}\text { Antidiabetic } \\
\text { Activity }\end{array}$ & $\begin{array}{l}\text { Cytotoxic } \\
\text { Activity }\end{array}$ \\
\hline Ethyl acetate extract & $12.8 \pm 1.3$ & $184.0 \pm 7.0$ & 641.0 & 54.1 & $>100$ \\
\hline$\underline{n}$-Butanol extract & $26.0 \pm 1.8$ & $300.0 \pm 5.0$ & 639.5 & 52.1 & 40 \\
\hline $\begin{array}{c}\text { Mixture } \\
(\mathbf{1 a}+\mathbf{1 b})\end{array}$ & $\mathrm{nd}^{\mathrm{c}}$ & $\mathrm{nd}^{\mathrm{c}}$ & $\mathrm{na}^{\mathrm{d}}$ & $\mathrm{na}^{\mathrm{d}}$ & $>100$ \\
\hline Vitamin C & $4.4 \pm 0.1$ & $4.1 \pm 0.1$ & & & \\
\hline Eserine & & & 0.018 & & \\
\hline Acarbose & & & & 30 & \\
\hline Doxorubicin & & & & & 0.1 \\
\hline
\end{tabular}

${ }^{\mathrm{a}}: \mathrm{IC}_{50}(\mu \mathrm{g} / \mathrm{mL}) ;{ }^{\mathrm{b}}:$ percent inhibition at $20 \mu \mathrm{g} / \mathrm{mL}{ }^{\mathrm{c}}:$ nd: not determined; ${ }^{\mathrm{d}}$ : not active at $1,000 \mu \mathrm{g} / \mathrm{mL}$.

\subsection{Antiacetylcholinesterase Activity}

The antiacetylcholinesterase activity of the $F$. lutea flower extracts was tested (Table 4). The ethyl acetate and $n$-butanol extracts exhibited weak anti-AChE activity, with $\mathrm{IC}_{50}$ values of $641.0 \mu \mathrm{g} / \mathrm{mL}$ and $639.5 \mu \mathrm{g} / \mathrm{mL}$, respectively. To our knowledge, no study of the anti-acetylcholinesterase activity of F. lutea or other Ferula species exists in the literature. Compounds $\mathbf{1 a}$ and $\mathbf{1 b}$ were also evaluated and were considered not active at $1000 \mu \mathrm{g} / \mathrm{mL}$.

\subsection{Antimicrobial Activity}

The antimicrobial activities of $F$. lutea flower extracts against microorganisms was examined in the present study and their potency were qualitatively and quantitatively assessed by the corresponding MIC and MBC values. We did not have enough material to evaluate the antimicrobial activities of the mixture 1a and 1b. The results are given in Tables 5 and 6. The ethyl acetate and $n$-butanol extracts had substantial antimicrobial activity against four bacteria and four Candida yeasts. The $n$-butanol extract (MIC and MBC: $1.25-2.5 \mathrm{mg} / \mathrm{mL}$ ) exhibited more interesting antimicrobial activities than the ethyl acetate extract (MIC and MBC: $10.00 \mathrm{mg} / \mathrm{mL}$ ), being especially active against Staphylococcus aureus with a MBC and MIC value of $1.25 \mathrm{mg} / \mathrm{mL}$.

Table 5. Antibacterial activity of $F$. lutea extracts.

\begin{tabular}{ccccccc}
\hline \multirow{2}{*}{ Microorganisms } & \multicolumn{2}{c}{ Ethyl Acetate } & \multicolumn{2}{c}{$\boldsymbol{n}$-Butanol } & Thymol & Gentamecin \\
\cline { 2 - 7 } & MIC & MBC & MIC & MBC & MIC & MBC \\
\hline Staphylococcus aureus ATCC 25923 & 10.00 & 10.00 & 1.25 & 0.02 & 0.20 & 0.15 \\
Enterococcus faecalis ATCC 29212 & 10.00 & $>10.00$ & 1.25 & 0.01 & 0.60 & 0.01 \\
Pseudomonas aeruginosa ATCC 27853 & 10.00 & 10.00 & 1.25 & 0.50 & 1.00 & 0.50 \\
Escherichia coli ATCC 25922 & 10.00 & $>10.00$ & 2.50 & 0.01 & 0.25 & 0.01 \\
\hline
\end{tabular}

MIC: Minimum inhibitory concentration $(\mathrm{mg} / \mathrm{mL})$; MFC: Minimum bactericidal concentration $(\mathrm{mg} / \mathrm{mL})$; Positive control Gentamecin and thymol $(\mu \mathrm{g} / \mathrm{mL})$. 
Table 6. Anticandida activity of $F$. lutea extracts.

\begin{tabular}{ccccccc}
\hline \multirow{2}{*}{ Microorganisms } & \multicolumn{2}{c}{ Ethyl acetate } & \multicolumn{2}{c}{$\boldsymbol{n}$-Butanol } & Thymol & Amphotericin B \\
\cline { 2 - 7 } & MIC & MFC & MIC & MFC & MIC & MFC \\
\hline Candida glabrata ATCC 90030 & 0.63 & 1.25 & 10.00 & 10.00 & 0.16 & 0.50 \\
Candida parapsilosis ATCC 22019 & 0.30 & 0.63 & 10.00 & 10.00 & 0.32 & 0.50 \\
Candida albicans ATCC 90028 & 0.30 & 0.63 & 10.00 & 10.00 & 0.13 & 0.50 \\
Candida kreseui ATCC 6258 & 0.30 & 0.63 & 10.00 & 10.00 & 0.32 & 0.50 \\
\hline
\end{tabular}

MIC: Minimum inhibitory concentration $(\mathrm{mg} / \mathrm{mL})$; MFC: Minimum fungicidal concentration $(\mathrm{mg} / \mathrm{mL})$.

Positive control amphotericin B and thymol $(\mu \mathrm{g} / \mathrm{mL})$.

Concerning Candida yeasts, the ethyl acetate extract (MIC and MBC: $0.30-1.25 \mathrm{mg} / \mathrm{mL}$ ) exhibited more interesting activities than the $n$-butanol extract (MIC and MBC: $10.00 \mathrm{mg} / \mathrm{mL}$ ). The ethyl acetate extract was especially active against $C$. parapsilosis, C. albicans and C. kreseui, with a MFC value of $0.625 \mathrm{mg} / \mathrm{mL}$ and MIC value of $0.3 \mathrm{mg} / \mathrm{mL}$; C. glabrata was found to be the most resistant species, with MIC of $0.625 \mathrm{mg} / \mathrm{mL}$ and MFC of $1.25 \mathrm{mg} / \mathrm{mL}$, compared to the positive control, thymol (MIC value of $0.16 \mu \mathrm{g} / \mathrm{mL}$ ). No data on the antimicrobial activity of F. lutea or other Ferula spp. extracts is available.

\subsection{Antidiabetic Activity}

The inhibitory activity of $F$. lutea extracts against $\alpha$-amylase is shown in Table 4 . The ethyl acetate and $n$-butanol extracts showed very good $\alpha$-amylase inhibitory activity. At $20 \mu \mathrm{g} / \mathrm{mL}$ of extracts, the inhibitory activity was $54.1 \%$ and $52.1 \%$ for the ethyl acetate and $n$-butanol extracts, respectively. The mixture of compounds $\mathbf{1 a}$ and $\mathbf{1 b}$ was poorly active $\left(\mathrm{IC}_{50}>100 \mu \mathrm{g} / \mathrm{mL}\right)$. Acarbose is less active than these two extracts. To our knowledge, no previously study on the antidiabetic activity of any Ferula species has been reported.

\subsection{Allelopathic Potential}

Methanol, in which the residues were dissolved, had no effect on germination hence any observed effects could be attributed to allelochemicals present in the organic extracts and compounds. Bioassays in the presence of extracts showed that the ethyl acetate extracts were the most effective. At the seventh day, the maximum toxicity of these extracts was registered, whereby the germination percentage was $0 \%$ (Figure 3 ). In the others cases, the maximum germination percentage values were $100 \%$ for the control and the $n$-butanol extract, but $87 \%$ for the mixture of compounds $\mathbf{1 a}$ and $\mathbf{1 b}$ (Figure 4).

For seedling lettuce growth, we recorded a strong activity for the ethyl acetate extract followed by the butanolic extract (BE), then compounds $\mathbf{1 a}$ and $\mathbf{1 b}$ (Figure 4). Indeed, we registered a total inhibition of root and shoot growth in presence of the ethyl acetate extract of Ferula plants (Figure 4). Relative toxicity of organic extracts is reported in the literature [27] where a higher phytotoxicity of methanol solutions of ethyl acetate extract is observed on lettuce compared to the $n$-butanol and water fractions. The result suggests that more phytotoxic substances were present in the ethyl acetate fraction 
than in the butanol one, resulting in more inhibitory effects on the test plant. Allelopathic potential of Ferula species is not cited in the literature.

Figure 3. Roots (R) and shoots length (PA), expressed in percent of control, of lettuce in presence $(1 \mathrm{mg} / \mathrm{mL})$ of (EAE), $n$-butanol extract (BE) and two diastereoisomers (1a and 1b) (C1) of $F$. lutea; 7 days after germination.

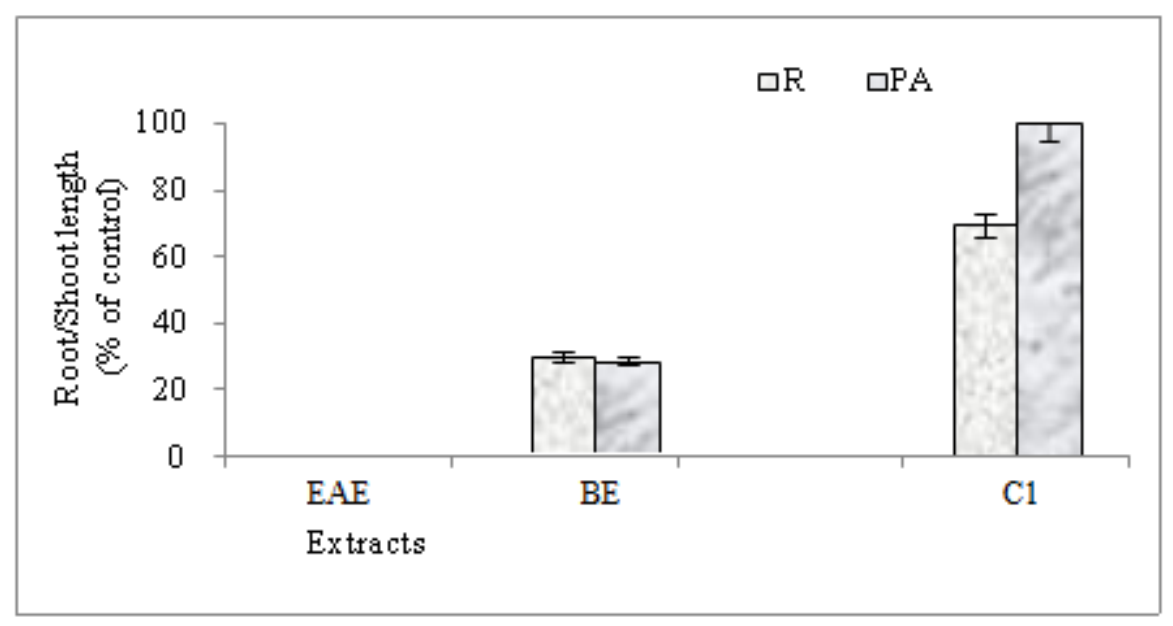

Figure 4. Germination of lettuce seeds in the presence $(1 \mathrm{mg} / \mathrm{mL})$ of distilled water (control), ethyl acetate (EAE), n-butanolic extract (BE) and two diastereoisomers (1a and 1b) (C1) of F. lutea.

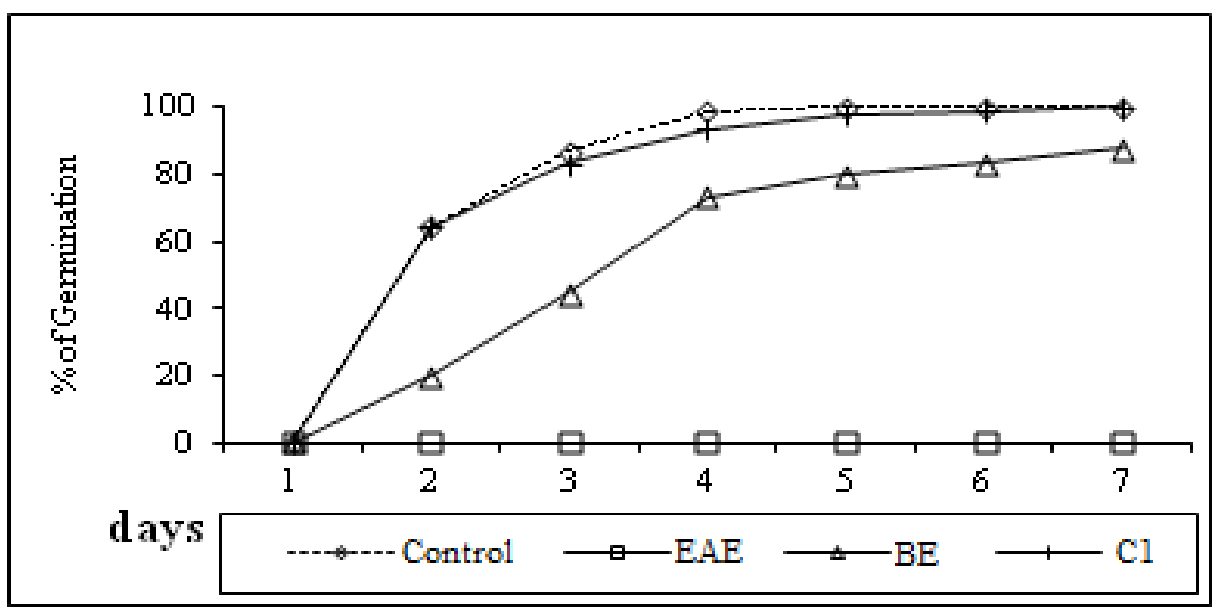

\subsection{Cytotoxicity Evaluation}

The results of the anticancer test on the isolated compounds, ethyl acetate and $n$-butanol extracts using the cancer cell Line, K562 (leukemia cell line) are given in Table 4. The cytotoxicity of the $n$-butanol extract was superior to that of all samples tested with an $\mathrm{IC}_{50}=40 \mu \mathrm{g} / \mathrm{mL}$, while the ethyl acetate extract and compounds $\mathbf{1 a}$ and $\mathbf{1 b}$ were poorly active $\left(\mathrm{IC}_{50}>100 \mu \mathrm{g} / \mathrm{mL}\right)$. The value of the cytotoxic activity of the n-butanol extract and is good, but not very high compared with the standard substance (doxorubicin). This is the first work citing the cytotoxic activity of $F$. lutea or other Ferula spp. 


\section{Experimental}

\subsection{General Experimental Procedures}

${ }^{1} \mathrm{H}-(300 \mathrm{MHz}),{ }^{13} \mathrm{C}-(75 \mathrm{MHz})$ and 2D NMR spectra of compounds $\mathbf{1 a}$ and $\mathbf{1 b}$ were recorded in $\mathrm{CDCl}_{3}$ with a Bruker NMR-300 spectrometer. The residual solvent resonances were used as internal references. Chemical shifts are expressed in ppm and coupling constants are given in Hertz.

\subsection{Collection of Plant Material}

F. lutea flowers were collected in the region of Béja (Tunisia) on April 2010 and identified by Professor Féthia Harzallah Skhiri, at the Laboratory of Genetic Biodiversity and Valorisation of Bioresources of the Higher Institute of Biotechnology of Monastir, Tunisia. A voucher specimen (F.L.F-10) was deposited in the same laboratory.

\subsection{Extraction and Isolation}

The fresh flowers of $F$. lutea $(5.8 \mathrm{~kg})$ were macerated at room temperature with $\mathrm{MeOH}-\mathrm{H}_{2} \mathrm{O}(7: 3$, $25 \mathrm{~L}$ ) at room temperature for 7 days and then concentrated by rotary evaporation leaving an oil layer $(5.8 \mathrm{~g})$ and an aqueous residue (only the organic solvent was evaporated at the low temperature used $-30{ }^{\circ} \mathrm{C}$ ) which was partitioned successively with ethyl acetate and $n$-butanol extracts, yielding, after evaporation of the solvents, the corresponding ethyl acetate $(56 \mathrm{~g})$ and $n$-butanol $(220 \mathrm{~g})$ extracts. From the all extracts, only the oil layer $(5 \mathrm{~g})$ was subjected to silica gel column chromatography eluting successively with pentane-ethyl acetate (95:5 to $100 \%$ ethyl acetate) to afford 14 fractions. The ninth subfraction (2.4 g) was chromatographed on silica gel eluting with pentane-ethyl acetate (7:3) to afford a mixture of compounds $\mathbf{1 a}$ and $\mathbf{1 b}(2 \mathrm{~g})$ that was difficult to separate. The ${ }^{1} \mathrm{H}-$ and ${ }^{13} \mathrm{C}-\mathrm{NMR}$ spectral data of two diastereoisomers compounds $(\mathbf{1 a}, \mathbf{1 b})$ are listed in Table 3.

\subsection{Determination of Total Polyphenol Contents}

The amount of total phenolic compounds was determined according to the method of Velioglu et al., [28] which uses the Folin-Ciocalteu reagent. Tested samples were prepared at a concentration of $1 \mathrm{mg} / \mathrm{mL}$. The sample $(100 \mu \mathrm{L})$ was transferred into a test tube and Folin-Ciocalteu reagent $(750 \mu \mathrm{L}$, previously diluted 10-times with deionised water) were added and mixed. The mixture was allowed to stand at a temperature of $25{ }^{\circ} \mathrm{C}$ for $5 \mathrm{~min}$, then saturated sodium carbonate $\left(\mathrm{Na}_{2} \mathrm{CO}_{3}\right)$ solution $(750 \mu \mathrm{L})$ was added to the mixture and then gently mixed. After standing at $25{ }^{\circ} \mathrm{C}$ for $90 \mathrm{~min}$, the absorbance was read at $725 \mathrm{~nm}$ using an UV-Visible spectrophotometer. A standard curve of gallic acid was used. Total phenolic content of plant parts was expressed as mg gallic acid equivalents per gram of dry weight (mg GAE/g DW) through the calibration curve with gallic acid. The calibration curve range was $0-250 \mu \mathrm{g} / \mathrm{mL}\left(R^{2}=0.99\right)$.

\subsection{Estimation of Total Flavonoid Contents}

The $\mathrm{AlCl}_{3}$ method [29] was used to determine the total flavonoid content of the sample extracts. Each extract $(1.5 \mathrm{~mL})$ was added to equal volumes of a solution of $2 \% \mathrm{AlCl}_{3} \cdot 6 \mathrm{H}_{2} \mathrm{O}(2 \mathrm{~g}$ in $100 \mathrm{~mL}$ 
methanol). The mixture was vigorously shaken, and absorbance at $367 \mathrm{~nm}$ was read after $10 \mathrm{~min}$ of incubation. Total flavonoid content was expressed as mg quercetin/g dry weight (mg QE/g DW), through the calibration curve of quercetin. The calibration curve range was $0-50 \mu \mathrm{g} / \mathrm{mL}\left(R^{2}=0.99\right)$.

\subsection{Antioxidant Activity by DPPH Assay}

Diluted methanol solutions of the samples at different concentrations ( $1 \mathrm{~mL}$ each) were mixed with $1 \mathrm{~mL}$ of a freshly prepared $(80 \mu \mathrm{g} / \mathrm{mL})$ methanol solution of DPPH. The resulted solution was incubated at $37{ }^{\circ} \mathrm{C}$ for $30 \mathrm{~min}$ after what the absorbance of the solution was measured at $517 \mathrm{~nm}$ [30]. Lower absorbance of the reaction mixture indicates higher free radical scavenging activity. Tests were carried out in triplicate. Decrease in absorption induced by the tested sample was compared to that of the positive control ascorbic acid. The capability to scavenge the DPPHradical was calculated using the following equation:

$$
\text { Inhibition ratio }(\mathrm{DPPH} \text { scavenging effect })(\%)=\left[\left(\mathrm{A}_{\text {control }}-\mathrm{A}_{\text {sample }}\right) / \mathrm{A}_{\text {control }}\right] \times 100
$$

The $\mathrm{IC}_{50}$ was calculated using the linear relation between the compound concentration and the probability of the percentage of DPPH inhibition.

\subsection{Antioxidant Activity by ABTS Assay}

ABTS was dissolved in water to a $7 \mathrm{mM}$ concentration and the ABTS radical cation was produced by adding potassium persulfate to a final concentration of $2.45 \mathrm{mM}$ [31]. The radical generation was completed in the dark at room temperature for $12 \mathrm{~h}$. This solution was then diluted with methanol to adjust its absorbance at $734 \mathrm{~nm}$ to $0.706 \pm 0.009$. To determine the scavenging activity, $1 \mathrm{~mL}$ of diluted $\mathrm{ABTS}^{+}$. solution was added to $1 \mathrm{~mL}$ of methanolic solutions of extract at different concentrations and the absorbance at $734 \mathrm{~nm}$ was measured $10 \mathrm{~min}$ after the initial mixing, using methanol as the blank. The percentage of inhibition was calculated by the equation:

$$
\left[\left(\mathrm{A}_{\text {control }}-\mathrm{A}_{\text {sample }}\right) / \mathrm{A}_{\text {control }}\right] \times 100
$$

where $\mathrm{A}_{\text {control }}$ is the absorbance of the control reaction containing all reagents except the tested sample, and $\mathrm{A}_{\text {sample }}$ is the absorbance of the test compound. Tests were carried out in triplicate. Ascorbic acid was used as the positive control. The $\mathrm{IC}_{50}$ was calculated using linear relation between the compound concentration and probability of the percentage of ABTS inhibition.

\subsection{Antiacetylcholinesterase Activity}

Briefly, $50 \mathrm{mM}$ Tris- $\mathrm{HCl}$ buffer $(100 \mu \mathrm{L}, \mathrm{pH} 8)$, the extract $(50 \mu \mathrm{L})$ and acetylcholinesterase solution $(10 \mu \mathrm{L})$ containing $0.26 \mathrm{U} / \mathrm{mL}$ were mixed in a microwell plate and left to incubate for $15 \mathrm{~min}$. Subsequently, a solution of AChI $(0.023 \mathrm{mg} / \mathrm{mL}, 50 \mu \mathrm{L})$ and $3 \mathrm{mM}$ DTNB $(140 \mu \mathrm{L})$ were added. The absorbance was read at $405 \mathrm{~nm}$ when the reaction reached equilibrium [32]. Eserine was used as a positive control and water served as a negative control and it was considered $100 \%$ activity. The percentage inhibition ((\%) IP) is given as follows:

$$
(\%) \mathrm{IP}=100-\left(\mathrm{A}_{\text {sample }} / \mathrm{A}_{\text {control }}\right) \times 100
$$


where $\mathrm{A}_{\text {control }}$ is the absorbance of the control reaction containing all reagents except the tested sample, and $\mathrm{A}_{\text {sample }}$ is the absorbance of the test compounds. Tests were carried out in triplicate and a blank with Tris-HCl buffer instead of enzyme solution was used.

\subsection{Cytotoxic Activity}

Cytotoxic activity of extracts against the human chronic myelogenous leukaemia cell line K562 was estimated by the 3-(4,5-dimethylthiazol-2-yl)-2,5-diphenyltetrazolium bromide (MTT) assay of Khlifi et al. [33]. The cells were grown in RPMI- 1640 medium supplemented with $10 \%$ faetal calf serum (Gibco, Gaithersburg, MD, USA), air and $5 \% \mathrm{CO}_{2}$. The resulting blue formazan product can be measured spectrophotometrically. The MTT colorimetric assay was performed in 96-well plates. Adherent human chronic myelogenous leukaemia K562 cells were seeded in a 96-well plate at a concentration of $10^{4}$ cells/well and incubated at $37{ }^{\circ} \mathrm{C}$ overnight in a $5 \% \mathrm{CO}_{2}$ enriched atmosphere. Cells in exponential growth phase were incubated at $37{ }^{\circ} \mathrm{C}$ for $72 \mathrm{~h}$ with each tested compound at concentrations ranging from 3.12 to $400 \mu \mathrm{g} / \mathrm{mL}$. After that, the medium was removed and cells were treated with MTT solution $\left(100 \mu \mathrm{L}, 0.2 \mathrm{mg} / \mathrm{mL}\right.$ in PBS) at $37{ }^{\circ} \mathrm{C}$ for $2 \mathrm{~h}$. MTT solution was then discarded and DMSO (500 $\mu \mathrm{L})$ was added to dissolve insoluble formazan crystals. Optical density was measured at $540 \mathrm{~nm}$. Each extract concentration was tested in triplicate. Doxorubicin was used as positive control.

\subsection{GC-MS Analysis}

The mass spectra of compounds $\mathbf{1 a}$ and $\mathbf{1 b}$ (diluted to $1 \%$ in the hexane) was achieved by coupled GC/MS analysis, on a system composed of a gas (HP-5890 II, Hewlett Packard Corporation, Palo Alto, California, CA, USA) coupled to a quadrupolar mass spectrometer (HP-MSD 5972 TO) operated in electron impact mode. The column used was an HP polar INNOWAX column of $30 \mathrm{~m}, 0.25 \mathrm{~mm}$, and $0.25 \mu \mathrm{m}$ film thickness. Its stationary phase was constituted of polyethylene glycol.

\subsection{Antidiabetic Activity}

Porcine pancreatic $\alpha$-amylase inhibitory activity was determined using a literature method [34]. Starch azure $(2 \mathrm{mg})$ was used as substrate and was suspended in $0.5 \mathrm{M}$ Tris- $\mathrm{HCl}(\mathrm{pH} 6.9,0.2 \mathrm{~mL})$ containing $0.01 \mathrm{M} \mathrm{CaCl}_{2}$. The tubes containing substrate solution were boiled for $5 \mathrm{~min}$. After $5 \mathrm{~min}$ of preincubation at $37^{\circ} \mathrm{C}$, extract dissolved in DMSO $(0.2 \mathrm{~mL})$ was added to the tube containing the substrate solution. A volume of porcine pancreatic amylase in Tris- $\mathrm{HCl}$ buffer $(0.1 \mathrm{~mL})$ was added and then incubated at $37{ }^{\circ} \mathrm{C}$ for $10 \mathrm{~min}$ and the reaction was stopped by adding $50 \%$ acetic acid $(0.5 \mathrm{~mL})$. The reaction mixture was centrifuged at $3,000 \mathrm{rpm}$ for $5 \mathrm{~min}$ at $4{ }^{\circ} \mathrm{C}$ and the absorbance was measured at $595 \mathrm{~nm}$.

\subsection{Antimicrobial Activity: Determination of Minimum Inhibitory (MIC), Minimum Bactericidal $(M B C)$, and Minimum Fungicidal Concentrations (MFC)}

The test microorganisms included the following Gram-positive bacteria: Staphylococcus aureus ATCC 25923, Enterococcus faecalis ATCC 29212; Gram-negative bacteria: Escherichia coli ATCC 
25922 and Pseudomonas aeruginosa ATCC 27853 and four Candida yeasts: Candida albicans ATCC 90028, C. glabrata ATCC 90030, C. kreusei ATCC 6258 and C. parapsilosis ATCC 22019).

The MIC values for the antibacterial and anticandidal screening were determined with the broth dilution method (microdilution using 96-well microplates) following the procedure described by Cintia et al. [35]. Briefly, all samples were prepared at a concentration of $10 \mathrm{mg} / \mathrm{mL}$ by dissolution of the extracts in $10 \%$ DMSO. The final concentrations of the plant samples tested ranged from 40 to $2 \times 10^{4} \mu \mathrm{g} / \mathrm{mL}$. The MIC of each sample was defined as the lowest concentration of oil that inhibited either the bacterial or candidal growth, after incubation at $37^{\circ} \mathrm{C}$ for 18 to $24 \mathrm{~h}$. The MBC and the MFC were determined by subculture on blood agar at $37^{\circ} \mathrm{C}$ for 18 to $24 \mathrm{~h}$. Thymol and gentamicin or thymol and amphotericin B were used as positive controls against the bacterial or candidal strains, respectively. The highest activities for each sample are presented in Tables 4 and 5 with the most noticeable antimicrobial activities against different strains shown in bold face. All tests were performed in triplicate.

\subsection{Allelopathic Potential}

The two samples concentrated from the ethyl acetate (EAE) and $n$-butanol (BE) extracts and the mixture $(\mathbf{1 a}+\mathbf{1 b})(\mathrm{C} 1)$ were again dissolved in $\mathrm{MeOH}$ to compare their phytotoxic effects. Five $\mathrm{mL}$ of each organic fraction at $6,000 \mathrm{ppm}$ and mixture $(\mathbf{1 a}+\mathbf{1 b})$ at $1,000 \mathrm{ppm}$ were placed in a Petri dish lined with a sheet of Whatman No. 1 filter paper and evaporated to dryness for $24 \mathrm{~h}$ at $24{ }^{\circ} \mathrm{C}$. After evaporation, distilled water $(5 \mathrm{~mL})$ was pipetted onto the filter paper. Methanol and distilled water were both were used as negative control. Seeds of lettuce were surface sterilized by immersing in $0.525 \mathrm{mg} / \mathrm{mL}$ sodium hypochlorite for $15 \mathrm{~min}$, and then were rinsed four times with deionised water, imbibed in deionised water at $22^{\circ} \mathrm{C}$ for $4 \mathrm{~h}$, and carefully blotted using a folded paper towel. Lettuce has been used as tested plant because it is very sensitive to chemicals at low concentration, although it sometimes overestimates the actual allelopathy [36]. Thirty swollen seeds were evenly placed on filter paper wetted with sample in each Petri dish. The germination was recorded at 24-h intervals till $144 \mathrm{~h}$. A seed was considered germinated when the radical protruded $\geq 2 \mathrm{~mm}$ [37]. Data were transformed to percent of control for further analysis. At 7th day after sowing, germination, shoot and root length of target species seedlings were measured. Data were transformed to percent of control for analysis.

\section{Conclusions}

F. lutea flowers were investigated for their chemical composition. Total phenols and flavonoids contents of extracts were determined and two diastereoisomers were isolated and identified. To the best of our knowledge, we report the first study on the antiacetylcholinesterase, antidiabectic, antimicrobial, allelopathic and cytotoxic activities of $F$. lutea flower constituents. We can conclude that the ethyl acetate extract has the highest antioxidant activity, the $n$-butanol one possesses an interesting cytotoxicity and finally both extracts have good antidiabetic activity. Nevertheless, it is interesting to continue the fractionation work to isolate the molecules responsible for the antioxidant, antidiabetic and cytotoxic activities. Compounds $\mathbf{1 a}$ and $\mathbf{1 b}$ were isolated as a mixture and their activities were evaluated for the first time. 


\section{Conflicts of Interest}

The authors declare no conflict of interest.

\section{References}

1. Downie, S.R.; Watson, M.F.; Spalik, K.; Katz-Downie, D.S. Molecular systematics of old world 2. Apioideae (Apiaceae): Relationships among some members of tribe Peucedaneaesensulato, the placement of several islandendemic species, and resolution within the apioidsuperclade. Can. J. Bot. 2000, 78, 506-528.

2. Drude, O. Die Natürlichen Pflanzenfamilien (In German); Engler, A., Ed.; Wilhelm Engelmann: Leipzig, Germany, 1898; Volume 3, pp. 228-232.

3. Pottier-Alapetite, G. Flore de la Tunisie: Angiospermes-Dicotyledones, Apétales-Dialypétales (In Spanish); Official printing: Tunis, Tunisia, 1979; pp. 607-609.

4. Tamemoto, K.Y.; Takaishi, B.; Chen, K.; Kawazoe, H.; Shibata, T.; Higuti, G.; Honda, M.; Ito, Y.; Takeda, O.K.; Kodzhimatov, O. Ashurmetov sesquiterpenoids from the fruits of Ferula kuhistanica and antibacterial activity of the constituents of F. kuhistanica. Phytochemistry 2001, 58, 763-767.

5. Gonzalez, A.G.; Barrera, J.B. Chemistry and sources of mono- and bicyclic sesquiterpenes from Ferula species. Prog. Chem. Org. Nat. Prod. 1995, 64, 1-92.

6. Appendino, G.; Spagliardi, P.; Cravotto, G.; Pocock, V.; Milligan, S. Daucane phytoestrogens: A structure-activity study. J. Nat. Prod. 2002, 65, 1612-1615.

7. Boulos, L. Algonac, Medicinal Plants of North Africa; ML. Reference Publications Inc.: Alyonae, MI, USA, 1983.

8. El-Razek, A.M.H.; Ohta, S.; Hirata, T. Terpenoid coumarins from the genus Ferula. Heterocycles 2003, 60, 689-716.

9. Suzuki, K.; Okasaka, M.; Kashiwada, Y.; Takaishi, Y.; Honda, G.; Ito, M.; Takeda, Y.; Kodzhimatov, O.K.; Ashurmetov, O.; Sekiya, M.; et al. Sesquiterpene lactones from the roots of Ferula varia and their cytotoxic activity. J. Nat. Prod. 2007, 70, 1915-1918.

10. Lamnaouer, D. Anticoagulant activity of coumarins from Ferula communis L. Therapie 1999, 54, 747-751.

11. Valle, M.G.; Appending, G.; Nano, G.M.; Picci, V. Prenylatedcoumarins and sesquiterpenoids from Ferula communis. Phytochemistry 1986, 23, 253-256.

12. Kartal, N.; Sokmen, M.; Tepe, B.; Daferera, D.; Polissiou, M.; Sokmen, A. Investigation of the antioxidant properties of Ferula orientalis L. using a suitable extraction procedure. Food Chem. 2006, 100, 584-589.

13. Alkhatib, R.; Hennebelle, T.; Joha, S.; Idziorek, T.; Preudhomme, C.; Quesnel, B.; Sahpaz, S.; Bailleul, F. Activity of elaeochytrin A from Ferula elaeochytris on leukemia cell lines. Phytochemistry 2008, 69, 2979-2983.

14. Abedi, D.; Jalali, M.; Asghari, G.; Sadeghi, N. Composition and antimicrobial activity of oleogumresin of Ferula gumosa Bioss. essential oil using Alamar Blue. Res. Pharm. Sci. 2008, 3, $41-45$. 
15. Fylaktakidou, K.C.; Hadjipavlou-Litina, D.J.; Litinas, K.E.; Nicolaides, D.N. Natural and synthetic coumarin derivatives with anti-inflammatory/antioxidant activities. Curr. Pharm. Des. 2004, 10, 3813-3833.

16. Özlem, B.; Gülçin, S.Ç.; Hanefi, Ö.; Stefano, D.; Karel, Š.J.H. Hepatoprotective and TNF- $\alpha$ inhibitory activity of Zosima absinthifolia extracts and coumarins. Fitoterapia 2011, 82, 454-459.

17. Salem, B.S.; Jabrane, A.; Harzallah-Skhiri, F.; Jannet, B.H. New bioactive dihydrofuranocoumarins from the roots of the Tunisian Ferula lutea (Poir.) Maire. Bioorg. Med. Chem. Lett. 2013, 23, 4248-4252.

18. Znati, M.; Jabrane, A.; Hajlaoui, H.; Bouajila, J.; Casanova, J.; Jannet, B.H. Chemical composition and in vitro evaluation of antimicrobial and anti-acetylcholinesterase of the flower oil of Ferula lutea L. Nat. Prod. Commun. 2012, 7, 947-950.

19. Razavi, S.M.; Nazemiyeh, H.; Hajiboland, R.; Kumarasamy, Y.; Delazar, A.; Nahar, L.; Sarker, S.D. Coumarins from the aerial parts of Prangos uloptera (Apiaceae). Rev. Bras. Farmacogn. 2008, $18,1-5$.

20. Baba, K.; Yoneda, Y.; Kozawa, M.; Fujita, E.; Wang, N.H.; Yuan, C.Q. Studies on Chinese traditional 1 medicine 'Fang-Feng' (II). Comparison of several Fang-Feng by coumarins, chromones and polyacetylenes. Jpn. J. Pharmacogn. 1989, 43, 216-221.

21. Abyshev, A.Z.; Abyshev, A.D. Coumarins of Seseli peucedanoides. Chem. Nat. Compd. 1984, 20, $230-231$.

22. Chacko, S.; Singh, O.V.; Sethuraman, M.G.; George, V. Coumarins from Heracleum. candolleanum. Indian Drugs. 2001, 38, 594-596.

23. Chen, I.S.; Chang, C.T.; Sheen, W.S.; Teng, C.M.; Tsai, I.L.; Duh, C.Y.; Ko, F.N. Coumarins and antiplatelet aggregation constituents from Formosan Peucedanum. japonicum. Phytochemistry 1996, 41, 525-530.

24. Tosun, A.; Baba, M.; Bahadir, O.; Okuyama, T. Coumarins isolated from the roots of Seseli resinosum in Turkey. Pharma. Biol. 2006, 44, 528-533.

25. Dehpour, A.A.; Ebrahimzadeh, M.A.; Nabavi, S.F.; Mohammad, N.S. Antioxidant activity of the methanol extract of Ferula assafoetida and its essential oil composition. Grasas Aceites 2009, 60, 405-412.

26. Ebrahimzadeh, M.A.; Nabavi, S.M.; Nabavi, S.F.; Dehpour, A.A. Antioxidant activity of hydroalcholic extract of Ferula gummosa Boiss roots. Eur. Rev. Med. Pharmacol. Sci. 2011, 15, 658-664.

27. Chon, S.S.; Jang, H.G.; Kim, D.K.; Kim, Y.M.; Boo, H.O.; Kim, Y.J. Allelopathic potential in lettuce (Lactuca. sativa L.) Plants. Sci. Hortic. 2005, 106, 309-317.

28. Velioglu, Y.S.; Mazza, G.; Gao, L.; Oomah, B.D. Antioxidant activity and total phenolics in selected fruits, vegetables, and grain products. J. Agric. Food Chem. 1998, 46, 4113-4117.

29. Lamaison, J.L.C.; Carnet, A. Teneurs en principaux flavonoids des fleurs de Crataegeus. monogyna Jacq et de Crataegeus. laevigata (Poiret D. C) en fonction de la vegetation (In French). Pharm. Acta. Helv. 1990, 65, 315-320.

30. Ebrahimabadi, A.H.; Ebrahimabadi, E.H.; Djafari-Bidgoli, Z.; Kashi, F.J.; Mazoochi, A.; Batooli, H.J. Composition and antioxidant and antimicrobial activity of the essential oil and extracts of Stachys. inflate Benth from Iran. Food Chem. 2010, 119, 452-458. 
31. Re, R.; Pellegrini, N.; Proteggente, A.; Pannala, A.; Yang, M.; Rice-Evans, C.J. Antioxidant activity applying an improved ABTS radical cation decolorization assay. Free Radic. Biol. Med. 1999, 26, 1231-1237.

32. Falé, P.L.; Borges, C.; Madeira, P.J.A.; Ascensão, L.; Araujo, M.E.M.; Florêncio, M.H.J. Rosmarinic acid, scutellarein 4'-methyl ether 7-O-glucuronide and (16S)-coleon E are the main compounds responsible for the antiacetylcholinesterase and antioxidant activity in herbal tea of Plectranthus. barbatus ("Falso Boldo"). Food Chem. 2009, 114, 798-805.

33. Khlifi, D.; Sghaier, R.M.; Amouri, S.; Laouini, D.; Hamdi, M.; Bouajila, J. Composition and anti-oxidant, anti-cancer and anti-inflammatory activities of Artemisia herba-alba, Ruta. chalpensis L. and Peganum harmala L. Food Chem. Toxicol. 2013, 55, 202-208.

34. Hansawasdi, C.; Kawabata, J.; Kasai, T. $\alpha$-Amylase inhibitors from Roselle (Hibiscus sabdariffia Linn) Tea. Biosci. Biotechnol. Biochem. 2000, 64, 1041-1043.

35. Cintia, S.G.K.; Smania, A., Jr.; Pedrosa, R.C.; Ferreira, S.R.S.J. Antioxidant and antimicrobial activities of shiitake (Lentinulaedodes) extracts obtained by organic solvents and supercritical fluids. Food Eng. 2007, 80, 631-638.

36. Olofsdotter, M. Rice-astep toward use of allelopathy. Agron. J. 2001, 93, 3-8.

37. Hou, J.Q.; Romo, J.T. Effects of chemicals stimulators on germination of Ceratoids lanata. Seed Sci. Technol. 1998, 26, 9-163.

Sample Availability: Samples of the compounds are available from the authors.

(C) 2014 by the authors; licensee MDPI, Basel, Switzerland. This article is an open access article distributed under the terms and conditions of the Creative Commons Attribution license (http://creativecommons.org/licenses/by/3.0/). 